\title{
Toward an Islamic Perspective on Creativity
}

\author{
Tengku Iskandar* \\ [...] Allah knows best who is astray and who is rightly guided. \\ Qur'ān 16:125
}

There is a sort of craze in many developed and developing countries about creativity and innovation, seeing it of high and increasing importance for economic and other social advancements. It is a reasonable desire to see (i) what perspective Islam's teachings might hold for the subject of creativity, and (ii) whether it is possible to argue that the teachings (effectively) enjoin 'being creative' as a way of life for Muslims, non-Muslims, etc., or as a mindset, or at the very least argue that 'being creative' is a recognised objective and value of Islam. The two became the twin purposes of the research, which concludes that Islam does enjoin individuals in society to strive towards the creation of things that are for them new and useful, with a caveat for Muslims that the understanding of the concept of creativity, as well as the uses to which the effort is directed, must be in accordance with Islam's teachings (other religious communities may choose caveats of their own). For Muslims, such a situation turns the activity into 'ibādah (servitude to Allah), making it inclusive of, but much more than about, increasing wealth and improving the material quality of life. This conclusion does not appear to be a bad bid'ah (bad innovation in the religion of Islam) as it has been deduced from Islam's more basic teachings and therefore cannot be said to be not part of the religion. It is well to remember that when he was young, Prophet Muhammad 'creatively' solved the problem of how to put the Black Stone back into place in the Ka 'bah. In addition, when we relate the subject of 'creativity' to the current madhāhib (schools of jurisprudence in Islam), we see obviously that a new madhhab could not have been established in history without substantial 'creative' contribution to the works of the existing madhähib.

If an 'ibādah perspective of an Islamically-sanctioned notion of creativity is accepted by Muslims everywhere, then the high and sincere level of dedication and fervour possible in religion can be rightfully harnessed - for the widespread promotion of 'creativity and innovativeness' in every society, which could greatly improve their position with respect to education, economic competitiveness, knowledge in technology and the sciences, among many other matters of importance in Islam.

* Tengku Iskandar is a Senior Analyst with IAIS Malaysia. This Viewpoint provides only selected glimpses into the findings of a preliminary research project of the same title being conducted by the author at IAIS Malaysia where the research idea was first conceived in July 2010. 
However, the first step is to ensure that such a perspective on creativity has the most solid foundation in the theology of Islam, otherwise widespread Muslim acceptance will not be achieved. Essential principles and values are not only necessary, but major and central here.

Holding a genuinely Islamic perspective on creativity is not a matter of current fashion, but permanent since it is seen as 'ibädah. However when the iron is hot it is time to strike - when creativity and innovativeness is in high fashion, it is opportune to advance the Islamic perspective on it to make Muslims and others permanently 'creative'.

The situation of Muslims as a whole over the last few centuries has hardly been as ideal as the above-constructed Islamic vision. But this has not always been the case; for example, for a period of about 650 years in post-Prophet Muhammad history, or roughly $700-1350$, Muslims were foremost in thought, learning, sciences and technology compared to other parts of the world at that time. Terms like ikhtiläf, tajdìd, ișlāh, ijtihād, bid 'ah, existing in the theology of Islam prove that a significant amount of the impetus for originality was present even in law and thought, let alone in the less profound areas of life.

Consistent with the low role of 'creativity' among Muslims in modern times, it is quite rare to find modern Islamic conceptual works on the subject of creativity (compare to the many more on the subject of reason or knowledge). The number of articles relating to creativity in the authoritative Oxford Encyclopedia of the Modern Islamic World (OUP, 1995) when these titles are searched for: creativity, creation, creator, originality, 'Islamic creativity', 'Islam and creativity', innovation, innovativeness - is only one, on 'innovation', which is treated under bid 'ah which is theological and legal and has a somewhat restrictive tone. Mention 'Islam and creativity' or 'Islamic creativity' and you would normally get a blank stare. If we were to compare various statistics that may correlate closely with the level of 'creative' activity in society (R\&D expenditure as a percentage of GDP, number of patents compared to population size, etc.) we would find that many Muslim-majority countries currently compare unfavourably with the levels seen in materially-developed countries. Such opinions or current practices are the opposite of what research might discover on Islam's teachings regarding creativity. Among Muslim laypersons there seems to not even exist a realisation of this very grave situation of how very low is their current 'creativity' compared to Islam's own teachings about the matter. If Muslim fervour and strong interest in creativity can be (re-)kindled, as hoped for and envisioned through the path above, Muslims will then do much that is necessary to promote their 'creativity and innovativeness'. There will then be much greater impetus for the deep study of the reasons in history that made them (and others) 'creative', and that made them (and others) subsequently abandon "creativity" for a time, a study that should be beneficial for the future. 
Henceforth, in principle anything that is believed to increase the 'creative' end-results of the striving of individuals and society should be encouraged or established. These include reasoning and critical thinking, self-confidence and boldness, courage, autonomy, specialist knowledge in many different areas, "creativity techniques", skilful planning, all aspects of the environment (cultural, social, educational, physical, political, etc.), among many other things. For the typical developing country, the scale of necessary changes may amount to a major overhaul of society, perhaps of civilisational scope and depth. A way must be found to manage the potential instabilities in the social order resulting from a significantly more autonomous society.

The qur'ānic term ulu 'l-albāb ('possessors of comprehending minds' - those skilled at reasoning and understanding) is seen as an important concept in current efforts at building an Islamic model for higher education and development. It is thought that there could be one way to re-interpret the term to include in it the idea of striving towards a useful and 'new' creation. Occasionally it may be beneficial to invent new (English) words when dealing with the subject of an Islamic conception of something, otherwise people may become confused or unsuitably impacted by the use of certain existing words that currently implicitly embody certain un-Islamic ideas, some of which may reflect secularism.

It may take many decades for the above social and intellectual changes to come to pass, if they do. Researchers are called upon to patiently persevere and join hands to strengthen the conceptual foundations of an Islamic perspective on creativity, not excluding the relevant works of past scholars, to achieve general Muslim agreement on this issue. The role of researchers reaches a certain point, after which the baton must be passed to the political leadership.

\section{Recommendations}

Many local and international scholarly conferences should be arranged for purposes that include the following:

- to come to an informed global Muslim consensus on Islam and creativity;

- to discover, and respond correctly to, every important Muslim objection to the widespread practice of creativity;

- to produce policy proposals for specific governments around the Muslim world.

It is timely (in fact, we are past the time) that an international Muslim 'Conference on Islam and Creativity' be held, analogous to the historically significant 'First International Conference on Islamic Education' held in Mecca in 1977. 
Some more suggestions:

- producing a fatwa $\bar{a}$ to enjoin the practice of 'creativity' as a form of 'ibādah (mandūb or wājib);

- immediate teaching and practising of 'creativity techniques' in Islamic religious schools, colleges, and universities, and also among all government employees;

- regular sermons at mosques, regular talks in radio channels, regular television programmes enjoining a 'creative' mind-set or way of life as a form of 'ibādah.

A deep and genuine Islamic perspective on creativity holds the possibility of clarifying, enriching and deepening the Malaysian Prime Minister Najib Tun Razak's call to make innovativeness a 'culture' in Malaysia. In addition, as part of the Islamic thrust for 'creativity', Muslims are enjoined to help in the promotion of a right form of creativity among non-Muslims, where necessary. 